\title{
Teacher Electronic Portfolio and its Relation to EFL Student Teacher Performance and Attitude
}

\author{
Areej T Alshawi (Corresponding author) \\ Curriculum and Instruction Department, College of Education, King Saud University, Saudi Arabia \\ E-mail: jeje.81@live.com \\ Yousif A. Alshumaimeri \\ Curriculum and Instruction Department, College of Education, King Saud University, Saudi Arabia
}

Received: $27-12-2016$

doi:10.7575/aiac.ijels.v.5n.1p.42
Accepted: 28-01-2017

URL: http://dx.doi.org/10.7575/aiac.ijels.v.5n.1p.42

Published: 31-01-2017

\begin{abstract}
E-portfolio is a promising approach to develop teachers into reflective practitioners who show that they can adapt to new technologies, new criteria, and new environments. The current research explored the quality of EFL student teachers' e-portfolios and their attitudes towards using them. The research was conducted on 30 EFL female student teachers at Princess Noura bint Abdulrahman University, Saudi Arabia. The participants were engaging in practical training at schools and reflecting their skills and experiences in their e-portfolios. This research posed further questions about the relationships between the quality of EFL student teachers' e-portfolios, their attitudes towards using them and their teaching performance. In order to explore the possible answers, the participants' teaching performance were observed, their e-portfolios were evaluated by a rubric, and a 24-item questionnaire was administered to them. The results proved high proficiency level of the EFL student teachers' e-portfolios and positive attitudes towards using eportfolios among EFL student teachers. Furthermore, the results denoted a statistically significant positive relationship between the quality of EFL student teachers' e-portfolio and their teaching performance. The results of this study may encourage policy makers to integrate the idea of e-portfolio and reflection as an effective component in teacher education and development.
\end{abstract}

Keywords: EFL student teachers, e-portfolio, teacher education and development, teachers' attitudes

\section{Introduction}

In Saudi Arabia, there is no doubt that the government has made remarkable efforts at every level of education to develop appropriate curriculums and train teachers efficiently. However, the field of teaching English has not pleased Saudi people and the level of student achievement is not satisfactory at a time in which English is used as a window for the outer world. Several studies that evaluated teaching English in Saudi Arabia revealed that one of the reasons of low student proficiency in English is the inadequacy of teachers. Fareh (2010) pointed out that improperly trained teachers could be one of the challenges of EFL program in the Arab world. Therefore, teacher education programs in Saudi Arabia should be evaluated and improved as the education environment keeps on changing with the introduction of new technology and changes in standardized methods of teaching.

Teaching English as a foreign language is mentally, psychologically, and physically challenging work. Thus, being qualified is not enough to be a good language teacher. There are three basic areas one EFL teacher should pose, as mentioned in Rahman and Al-Haisoni's study (2013), proper knowledge of English language, well awareness of how to teach English, and understanding how students learn and what it takes to reach them effectively. These areas should be the basics with which teacher training programs are concerned. One essential skill, language teachers need to be trained to have as a first step to develop themselves, is reflection. The qualified teacher is not only a master of procedure but also of the content and reasoning, and capable of explaining why something is done. The teacher is capable of reflection leading to self-knowledge, the metacognitive awareness (Shulman, 1986). By doing so, a teacher will be aware of her students' learning styles, needs and interests as well as her ability as a teacher to reveal their potential. Therefore, EFL teachers should be trained how to review and reflect on their own practice. So, they can seek to expand their English language knowledge and try to find new ideas and practices that they can apply in their own classrooms.

Teacher reflection is one of the methods to develop teachers' skills, knowledge, and techniques. Teacher reflection shows the way of how teachers may interrogate their practices; pose questions concerning the effectiveness of their work, and meet students' needs and expectations (Lyons, 1998). The purpose of teacher reflection is not only to change the style of teacher's work but also to promote the evolution in work and understanding of what can be done to help students benefit with the chosen teaching practices. Reflective practice develops creative skills of teachers (Kemmis, 1994). Reflectivity increases the abilities of teachers to plan, organize, critically think, observe and create. It enables 
teachers to learn new and variety strategies of teaching and learning in the process of education. Reflective teachers offer a variety of materials to students for learning and experience (Ahmad, Said, Zeb, Rehman, Ahmad \& Khan, 2013). There are many ways on how to promote teacher reflective practice, and electronic-portfolios are one of effective approaches to achieve this practice.

Electronic-portfolios are considered a promising and advanced approach in teacher education in many countries (Granberg, 2010). They serve one of the main purposes in teacher education, which is the contribution to constructivist learning (Mair, 2012). Reflective writing in e-portfolios can work as means for fostering critical reflection among student teachers (Lumpe \& Wicks, 2011). This reflective practice helps student teachers analyze their own previous knowledge and attitudes, realize how these understandings developed, study the effects they have on actions and behavior, and think about alternative conceptions and principles that may be more useful in teaching (Abdal-Haqq, 1998).

\subsection{Statement of the Problem}

Many Saudi English teachers are using teacher-centered rather than learner-centered activities in their classes and emphasizing on rote learning. The reason behind this could be attributed to the lack of professional development they receive. English language teachers are provided with only limited information on how to improve themselves. They can develop themselves continuously and efficiently with self-reflection. One way to encourage reflection is through the development of an electronic portfolio. Many research studies have been conducted to document the use of e-portfolio in EFL teacher education and to study its benefits in teaching practice; however, based on the researcher's knowledge, only few related studies have been conducted at universities in the Arab region. Thus, the researcher attempts to show teacher e-portfolios' necessity for teacher education and development and their relation to teacher performances and attitudes towards using them.

\subsection{Definition of Terminology}

- Teacher e-portfolio: a collection of artifacts, including short résumé, samples of work, resources, teachers' reflective notes, and accomplishments demonstrated in a multimedia through a website.

- Student teacher: A student who is in a teacher education program at University

- Teaching Performance: The knowledge, skills and dispositions that are crucial for a teacher to be effective

- Attitude: a way of thinking or feeling about using the e-portfolio or a way of behaving that is caused by using the e-portfolio.

\section{Literature Review}

\subsection{Reflective practice and e-portfolios}

According to Noormohammadi (2014), teacher reflection is the act of studying beliefs, objectives, and practices to promote teacher education. Reflection is one of the fundamental competencies of teachers. For instance, the practice helps teachers identify their strengths and weaknesses. The lack of such awareness would make teachers develop difficulties in executing their duties. However, reflection does not entail only realizing the strong and weak points. It should encompass the analysis of a determined area and schedule of subsequent responses. Reflection helps shape one's attitude towards change (Loughran, 1996). The practice is both cognitive and affective and it entails readiness to initiate change (De Grez, Valcke, \& Roozen, 2009).

Various theorists have addressed how reflection is applied in the EFL teacher education. Theorist, Donald Schon, seems to be consistent with various studies that describe the three types of reflective practice (Choy, 2012). Reflection-inaction, reflection-on-action, and reflection-for-action are the widely recognized types of the practice. Reflection-onaction happens when teachers reflect on their daily practices such as classroom proceedings and utilize the information to improve their practices. The purpose of this type of reflection is to help teachers increase effectiveness. This skill should be grasped early during teaching experiences to confirm that service teachers are proficient in reflecting on topics that have been taught (Cimermanova, 2015). Reflection-in-action happens during lessons and it entails responding immediately to increase efficacy. In this case, teachers can make desired adjustments in the midst of teaching (Choy, 2012). Finally, reflection-for-action is the way of evaluating events and experiences with the aim of initiating change in the future. Essentially, this form of reflection seeks to steer positive future action. Teachers adopt this model to plan by assessing the details of past events and what they established after the class. This aspect assists teachers in detecting any inconsistency between their belief system and real practices.

According to Cohen-Sayag (2012), e-portfolios are the best techniques to promote critical reflection. E-portfolios are digital collections of artifacts, which may represent an individual, group, organization, or institution. These portfolios can be demonstrated in multimedia such as video or audio and can be positioned on CDs or DVDs, or on a website. Eportfolios started being used in the 1990s with students in higher education as a way to display their learning experiences and skills (Lorenzo \& Ittelson, 2005). E-portfolio allows learners to be more aware of their progress and transition to professionals. Building e-portfolio helps teachers think critically about the content of a certain subject. Besides, e-portfolio enables EFL teachers to receive feedback and criticism from peers. Consequently, teachers get in a better position to learn their strengths and weaknesses. In this way, learning becomes visible since teachers can link their learning to others. 
However, implementing e-portfolio may not necessarily work. The value of e-portfolio for teacher trainees relies on how it is implemented, the practices of the institution, and the wider support mechanisms. E-portfolios can be the basis of ensuring reflection and making learning visible. As noted by Loughran (1996), experienced e-portfolio users are aware that successful reflection does not just occur. Professional and deliberate training is needed from the staff. Through e-portfolio, integrative learning is facilitated to enable teachers to shift from one experience to the next with a good understanding of its connection to other ideas.

\subsection{Use and Advantages of teacher e-portfolios}

E-portfolios provide more advantages as compared to paper-based portfolios. According to Herrington, Couros, and Irvine (2013), both e-portfolio and paper-based portfolio promote learning, but some aspects make e-portfolio more desirable to use. The commonly stated reasons for the use of e-portfolio include increased portability and remote access. Studies indicate that adopting e-portfolio can improve the teachers' completion times up to about 30\% as opposed to when using paper-based portfolio for the same task (Cohen-Sayag, 2012). Teachers can carry a USB or access their database through an Internet-linked medium. Furthermore, teachers can increase connections between various portfolios via hyperlink.

Traditionally, teachers would gather their work in folders or floppy disks. These formats have become obsolete due to the further developments attained in the field of information technology (Pultorak, 2010). E-portfolios have provided a digital platform where work is stored and retrieved swiftly. An e-portfolio designer needs to have technology skills such as digital publishing, file management, and other web design tools. Therefore, a teacher e-portfolio should include a tittle page bearing the designer's name, contact address, and educational credentials. A table of contents should be present to display links to the details of the portfolio. A layout of key contents of the portfolio is present. The portfolio should include artifacts that represent the authentic products of the author. Artifacts can take any form such as images, videotapes, audios, or documents.

While teachers work on their e-portfolios, they improve their language skills, pedagogical knowledge, content knowledge, and technological knowledge. Alawadat (2013) proposed more merits of the reflective process such as the teachers' capability to initiate changes in methodology coupled with learning to link class experiences and its details to integrate changes in teaching. Furthermore, the frequent use of electronic devices helps teachers enhance their ICT skills. The escalating role of IT in schools makes the demonstration of technology efficacy highly important (Sweigard, 2007). Learners who build portfolios show their knowledge of hardware and the connection of the two for the aim of generating essential learning tools. E-portfolios enhance the language skills and EFL teachers' speaking proficiency (Strudler \& Wetzel, 2011). Research by Sweigard (2007) reveals that the continuing of e-portfolio usage promotes substantial oral and language learning.

To deepen initiatives and thrive, the education field must identify and employ effective strategies. A group of research works share that e-portfolio has the potential to play a significant role in the growth of the education sector and the fulfillment of these goals. Integrative e-portfolios can support reflective practices. Such initiatives enhance teacher success, broaden their thinking, and expose them to various factors that catalyze institutional change. In Saudi Arabia, there is a need to facilitate the incorporation of e-portfolio to ensure quality education and improve the chances of the students competing internationally. Therefore, this research intends to confirm that continued engagement in e-portfolio approaches would shape the teachers' capacity to reflect and ensure a stable education system.

\subsection{Research Questions}

In doing so, the research seeks to answer the following questions:

1. What is the significance of difference between the quality of EFL student teachers' e-portfolios and the test value?

2. What is the significance of difference between the attitudes of EFL student teachers towards using eportfolios during their teaching practice and the test value?

3. What is the statistical significance of the correlation between the EFL student teacher's quality of eportfolio, attitudes towards using e-portfolios and teaching performance?

\section{Methods}

\subsection{Research Method}

In the attempt to show the necessity of e-portfolios for teacher education and development, the descriptive analytical method was implemented to describe and analyze the information gathered. The researcher used the content analysis method to evaluate EFL student teachers' e-portfolios by utilizing a rubric, designed in the light of the previous reviewed literature. Then, the researcher linked between causes (EFL student teachers' knowledge and skills) and effect (their scores). In addition, the researcher used the survey method to reveal and investigate EFL student teachers' attitudes towards their e-portfolios. The relationships between the variables were measured to explore their existence and strength.

\subsection{Participants}

The population of the study consisted of all EFL student teachers, who were studied at level eight in the College of Education at Princess Noura bint Abdulrahman University in Saudi Arabia. They were also engaged for practical 
training in primary schools at the second semester of the year 2015/2016 and were required to develop paper-based portfolios as one of the requirements of the practical training course. The researcher selected deliberately the participants of this study who had some awareness of e-portfolios, and had created personal e-portfolios previously. They were 30 EFL student teachers. Moreover, the participants were given lessons on how to utilize the electronic portfolios perfectly.

\subsection{Procedures}

Primary sources of data collection for this study were the e-portfolios that student teachers developed, their responses to the questionnaire and their teaching performance scores. At the beginning, the research instruments were prepared after a careful literature review, and then measured to be reliable and valid. Later, the researcher took permission from PNU to lead the study in its EFL classes. Thirty EFL student teachers agreed to participate willingly after being informed about the purpose of the study. During their practical training course, each student teacher established an account on any freely available websites (such as wix.com) and participated in training sessions on setting up and using these websites. They were required to collect artifacts such as lesson plans, class projects, class presentations, self- evaluation and peer-evaluation sheets, reflective narratives and instructor feedback. Their e-portfolios were demonstrated in multimedia such as text files, graphics, videos, or web links. Throughout the semester, their teaching performance in schools were observed and evaluated by English cooperative teachers once a week, and by University faculty members once every other week using the evaluation form. At the end of the semester, the e-portfolios were evaluated using the rubric and given scores to demonstrate their quality. Furthermore, the questionnaire was sent to the participants via their e-mail addresses, and descriptive statistics for the variables were analyzed for the data.

\subsection{Instruments}

\subsubsection{The Evaluation Rubric for E-portfolios}

Heidi Andrade (n.d.) defined a rubric as "a document that articulates the expectations for an assignment by listing the criteria, or what counts, and describing levels of quality from excellent to poor. E-portfolio rubrics can provide parameters and offer guidance both to students preparing portfolios and to teachers evaluating them" (p.8). The rubric should specify what e-portfolios may include and what level of quality may be given to each component. To evaluate the quality of the e-portfolios, the researcher adopted a rubric, developed by the University of Wisconsin (Vandervelde, 2016), and made some modifications to what Saudi universities used to. In this rubric, the researcher specified six domains and described each level of quality from excellent to unsatisfactory in each domain. Also, the researcher distributed percentages for each domain from the total grade of the e-portfolio (Appendix A).

\subsubsection{The Questionnaire}

The researcher built a Likert-scale questionnaire to explore the attitudes of EFL student teachers towards using eportfolio during their teaching practice. The questionnaire had 24 items, which were grouped, under three domains: affective domain, cognitive domain, and behavioral domain (Appendix B).

\subsubsection{The Teaching Performance Evaluation Form}

The teaching performance of EFL student teachers was evaluated by an evaluation form consisting of 25 items. The form used examines instructional competence regarding: planning, learning and learners' development and differences, content (content knowledge and application), instructional practice: (assessment, planning for instruction, and instructional strategies). This form was derived from Instruction and Curriculum Department at PNU.

\subsection{Validity and Reliability}

In terms of regarding validity, three experts in Curriculum and English Language Methodology reviewed the evaluation rubric and provided feedback. They determined the degree of proficiency as (80\%) divided as 24 in completeness of content and reflection/critique and 8 in use of multimedia, navigation, layout and quality of writing. Additionally, the experts were asked to assess the relevance and clearness of the questionnaire items. They provided suggestions and remarks which aided in considering and restating some items. A pilot survey was conducted prior to the implementation of the questionnaire to avoid any difficulties that might arise during final implementation. The sample for the pilot survey, which was 20 EFL students, was randomly selected.

For reliability, the researcher used inter-rater reliability to assess the degree to which different raters agree in their assessment of three selected e-portfolios using the evaluation rubric. The raters were two teachers in the same college. To get an honest and objective measurement, the participants' names were hid. A high degree of reliability was found between the measurements. The rubric was reliable at 1.000 Cronbach's Alpha. Cronbach's alpha reliability coefficient usually ranges between 0 and 1; the nearer it is to 1.0, the higher the internal consistency of the items in the scale (Cronbach, 1951). Moreover, Cronbach's alpha was performed on the questionnaire to measure its internal consistency. It was reliable at 0.914 Cronbach's Alpha.

\subsection{Data Analysis}

The EFL student teachers' e-portfolio scores were collected manually and analyzed by SPSS program. T test was calculated to compare the means of student teachers' results in the e-portfolio evaluation rubric, and the selected value $(80 \%)$. 
Their questionnaire results were collected manually and analyzed by SPSS program. First, descriptive statistics were used to determine means of students' responses on the Likert-scale. Secondly, one sample (t) test was run to compare the general mean of statements and the mean of student teachers' responses.

Their teaching performance scores were collected manually and related to their previoud data by SPSS. Then, Pearson correlation coefficient was run to find the relationships between EFL student teachers' performance, e-portfolios' quality and attitudes towards their use.

\section{The Results}

The aim of this study was to reveal the need for e-portfolios in teacher education and development. The research questions were 1. What is the significance of difference between the quality of EFL student teachers' e-portfolios and the test value? 2. What is the significance of difference between the attitudes of EFL student teachers towards using eportfolios during their teaching practice and the test value? 3. What is the statistical significance of the correlation between the EFL student teacher's quality of e-portfolio, attitudes towards using e-portfolios and teaching performance?

To answer the first question, the researcher used one-sample T test to compare the means of student teachers' results in the e-portfolio evaluation rubric, and the selected value (the degree of proficiency which the experts determined as $(80 \%)$ as shown in Table 1.

As Table 1 shows, there was a significant difference in the overall mean of EFL student teachers' results for their eportfolios, and the selected value $80 \%$, as the overall percentage of students' mean $(84 \%)$ was above the percentage of standard mean $(80 \%)$. This result means that the quality of EFL student teachers' e-portfolios was proficient.

Table 1. One- sample T test to compare the means of student teachers' scores in the e-portfolio evaluation rubric, and the selected value $(80 \%)$

\begin{tabular}{lcccccc}
\hline \multicolumn{1}{c}{ Criteria } & Mean & $\begin{array}{c}\text { Std. } \\
\text { Deviation }\end{array}$ & $\begin{array}{c}\text { Percentage of } \\
\text { Standard Mean }\end{array}$ & $\begin{array}{c}\text { Percentage of } \\
\text { Students Mean }\end{array}$ & T value & $\begin{array}{c}\text { Sig. (2- } \\
\text { tailed) }\end{array}$ \\
\hline Content & 26.5000 & 2.58310 & $80 \%$ & $88.3 \%$ & 5.301 & .000 \\
Reflection & 21.0667 & 4.41731 & $80 \%$ & $70.2 \%$ & -3.637 & .001 \\
Multimedia & 9.7667 & .81720 & $80 \%$ & $97.7 \%$ & 11.841 & .000 \\
Navigation & 9.4000 & .62146 & $80 \%$ & $94 \%$ & 12.339 & .000 \\
Layout & 9.9667 & .18257 & $80 \%$ & $99.7 \%$ & 59.000 & .000 \\
Writing & 7.4333 & 1.73570 & $80 \%$ & $74.3 \%$ & -1.788 & .084 \\
Total & 84.0000 & 7.08081 & $80 \%$ & $84 \%$ & 3.094 & .004 \\
\hline
\end{tabular}

It is obvious from the table that all percentages of students mean were above the percentage of standard mean except in the criteria: reflection and quality of writing. As the researcher believed, this reasonably low percentage was due to the amount of grammatical mistakes and weak writing skills she found in student teachers' e-portfolios while evaluating. It is worth-mentioning that the highest percentages were under the criteria of multimedia, navigation and layout, and this result showed EFL student teachers' high knowledge of technology and computer.

Regarding the second question, the questionnaire was administered to the 30 EFL student teachers and their responses were analyzed by the SPSS program, using descriptive statistics to determine means of students' responses on the Likert scale: strongly agree, agree, neutral, disagree, and strongly disagree. The questionnaire consisted of three domains, which are affective, cognitive and behavioral to interpret the EFL student teachers' attitudes completely. Generally, the results of their responses to the three domains were positive, and that they agree that the e-portfolio approach contributed to their growth, benefited their teaching, enhanced their reflection and increased their technology skills and subject knowledge.

In order to know if there was a statistically significant difference between the general mean of statements 72 and the mean of student teachers' responses 98.50 , one sample ( $\mathrm{t}$ ) test was run to compare between the two means. The result is in Table 2:

Table 2. One Sample (t) Test

\begin{tabular}{ccccccc}
\hline & $\mathrm{N}$ & Mean & Mean Difference & $\mathrm{df}$ & $\mathrm{t}$ & Sig. (2-tailed) \\
\hline Sample & 30 & 98.50 & 26.500 & 29 & 12.605 & .000 \\
\hline
\end{tabular}


The result in Table 2 showed that there was a statistically significant difference between the two means $(\alpha \leq .05)$. The mean of student teachers' responses to the items in the questionnaire was statistically significantly higher than the overall mean of statements, $t(29)=12.605, p=.000$. This means that the study sample had a notably positive attitude towards using e-portfolios. Therefore, to answer the research question, the attitudes of EFL student teachers towards the use of e-portfolio in their teaching practice were statistically positive. This result probably pointed that EFL student teachers were attentive of the significance of e-portfolio integration in teacher education and its role to enhance teacher self-development.

Moreover, a closer look at the results showed that the responses to the different domains reflect a comprehensive view of attitudes. The highest mean score of 4.77 was for behavioral domain followed by cognitive domain with a mean of 4.12, then the affective domain 3.98. Additionally, the researcher preferred to add more information on the relations between the three domains of attitudes towards using e-portfolios among EFL student teachers to prove the importance of each domain as a part of a whole. Pearson correlation coefficient was run to compare between the means of the affective, cognitive and behavioral domains. The result is in Table 3.

Table 3. Pearson correlation coefficient to find the relationship between EFL student teachers' affective, cognitive and behavioral attitudes

\begin{tabular}{llccc}
\hline & & $\begin{array}{c}\text { Affective } \\
\text { component }\end{array}$ & $\begin{array}{c}\text { Cognitive } \\
\text { Component }\end{array}$ & $\begin{array}{c}\text { Behavioral } \\
\text { Component }\end{array}$ \\
\hline Affective component & Pearson Correlation & 1 & \\
& Sig. (2-tailed) & 30 & \\
Cognitive Component & $\mathrm{N}$ & $.655^{* *}$ & \\
& Pearson Correlation & .000 & \\
& Sig. (2-tailed) & 30 & \\
Behavioral Component & $\mathrm{N}$ & $.777^{* *}$ & $.748^{* *}$ \\
& Pearson Correlation & .000 & .000 \\
& Sig. (2-tailed) & 30 & 30 \\
\hline
\end{tabular}

**. Correlation is significant at the 0.01 level (2-tailed).

As shown in the table, a moderate relation between EFL student teachers' affective attitudes and their cognitive attitudes was found since $\mathrm{r}=0.655, \mathrm{p}=.000$. Besides, there was a high relation between their affective attitudes and their behavioral attitudes since $r=0.777, p=.000$. Also, there was a high relation between their cognitive attitudes and behavioral attitudes since $r=0.748$ and $p=.000$, where $r$ is Pearson correlation coefficient. Based on the results, there were significant positive relations between EFL student teachers' affective attitudes, their cognitive attitudes and their behavioral attitudes. This indicated that as long as EFL student teachers' affective attitudes towards e-portfolios were high, their cognitive and behavioral attitudes would be enhanced and vice versa. Furthermore, the results showed that EFL student teachers' attitudes towards e-portfolios were very positive for most items in all the areas, except for two items. Means of responses ranged from 2.97 to 4.50 with the highest scores for "I feel proud of my work", "I improved my technology skills" and "I used feedback from my supervisor to improve my work". On the other hand, the lowest scores were for "I was confused at the whole experience" and "I have found difficulties in selecting artifacts to document my work".

In order to know if there were statistically significant correlations between EFL student teachers' performance, eportfolios' quality and attitudes towards their use, Pearson correlation coefficient was run to compare between the means.

As shown in Table 4, there was no relation between EFL student teachers' scores in e-portfolios and their attitudes towards using e-portfolios since $r=0.284, \mathrm{P}$-value was more than $.05(\mathrm{p}=.129)$. Also, there was no relation between EFL student teachers' attitudes and their teaching performance since $p>.05(p=0.902)$. Nonetheless, there was a low relation between EFL student teachers' scores in their e-portfolios and their teaching performance since $r=0.362, p$ $=.049$, where $\mathrm{r}$ was Pearson correlation coefficient. This result denoted that there was a positive significant relation between the quality of EFL student teachers' e-portfolios and their teaching performance. This result indicated that as long as the quality of EFL student teachers' e-portfolios were high, their teaching performance would be better. 
Table 4. Pearson correlation coefficient to find the relationship between EFL student teachers' performance, e-portfolios' quality and attitudes towards their use.

\begin{tabular}{llccc}
\hline \multirow{2}{*}{ Attitudes } & & Attitudes & Performance & $\begin{array}{c}\text { Total } \\
\text { marks }\end{array}$ \\
& Pearson Correlation & 1 & & \\
& Sig. (2-tailed) & & & \\
& $\mathrm{N}$ & 30 & & \\
Performance & Pearson Correlation & .023 & & \\
& Sig. (2-tailed) & .902 & & 1 \\
E-portfolio's & $\mathrm{N}$ & 30 & $.362^{*}$ & \\
quality & Pearson Correlation & .284 & .049 & 30 \\
& Sig. (2-tailed) & .129 & 30 & \\
\hline
\end{tabular}

* Correlation is significant at the 0.05 level (2-tailed).

\section{Discussion and Conclusion}

\subsection{Discussion}

Firstly, the study analyzed the quality of student teachers' e-portfolios using the evaluation rubric and proved that the overall quality was proficient (the overall proficiency level) since the overall students mean was statistically higher than the standard mean. Hence, the researcher might refer this result to student teachers' awareness of the idea of e-portfolio, its significance, steps of its preparation and the criteria in which it was evaluated. This result supported a previous study conducted by Abu Mutlaq (2012). Abu Mutlaq concluded that students' perception of the purposes behind e-portfolio usage and the guidelines they received contributed to their motivation to accomplish them perfectly (2012).

It is worth-mentioning that after evaluating student teachers' e-portfolios, most of them got low percentages in certain criteria of e-portfolio while in other criteria they got very high ones. For the low percentages in the criteria of reflection and quality of writing, the researcher supposed that EFL student teachers probably lacked the skill of reflective writing, which is in teacher e-portfolio considered as academic writing. Academic writing style is more careful and considered than everyday writing or speech. This means that EFL student teachers' writing should be formal, precise and accurate. Besides, they should write more than their feelings on a particular subject. There should be analysis and personal reflection that have significant depth and breadth (Reflective writing, n.d.). Remarkably, the low percentage of reflection in e-portfolio evaluation was found in other previous studies. A study conducted by Chien proved that selfreflection was neglected in the e-portfolios of students (2013). In another study, the researchers analysed 41 candidates' e-portfolios and showed that a large amount of blog posts were at a low level of reflection and some were non-reflective (Chen, Lumpe, Bishop, 2013). As noted by Loughran (1996), professional and deliberate training is needed from eportfolio users to get successful reflection. On the contrary, the high percentages in the criteria of multimedia, navigation and layout could be attributed to student teachers' experiences in dealing with websites and media in previous syllabuses such as computer-assisted language learning.

Secondly, the study confirmed the positive attitudes towards using e-portfolios with EFL student teachers. This result could be attributed to the fact that the e-portfolio represents a turn from traditional methods of teacher education to new methods based on the e-portfolio contents such as artifacts and projects, which integrated multimedia applications that were interesting and motivated the students to learn. As Meyer, Abrami, Wade, Aslan, and Deault, stated (2010), electronic tools such as e-portfolios, have been implemented to meet the requirements of the digital age in today's sophisticated classrooms. Another possible explanation for the development of positive attitudes towards using eportfolios was the high computer skills among student teachers. Undoubtedly, the EFL student teachers in this study showed a notable willingness and preference in using e-portfolios in language teaching, though they seemed to need more time and practice to develop their e-portfolios. Moreover, as building the e-portfolio depended mostly in writing skills, student teachers might need intensive lessons and workshops to improve writing their lesson plans and reflections. This positive result of EFL student teachers' attitudes towards using e-portfolios aligned with a group of prior studies. Yusuf and Tuisawau (2011), alwraikat (2012) and Winsor, Burr, and Reeves (1999) found that participants were willing to use e-portfolios to develop a positive attitude towards their teaching through reflection.

Notably, the results of the questionnaire showed that EFL student teachers' attitudes towards e-portfolios were very positive for most items in all the areas, except for two items. The highly positive responses for the items: "I feel proud of my work", "I improved my technology skills" and "I used feedback from my supervisor to improve my work" suggested significant benefits of using e-portfolios. First, people liked to see and show off their achievements in a tangible way as e-portfolios did. Also, e-portfolios were a method to showcase technology skills, and to model technology skills for others. In addition, e-portfolios facilitated receiving ideas and feedback. Students could receive 
feedback rapidly and regularly throughout the process of developing their e-portfolios. Interestingly, the very positive attitudes to the three mentioned items can be seen in other previous studies. For the first statement, a study conducted by Winsor, Burr, and Reeves (1999) demonstrated learners' pride of their growth while using e-portfolios and their desire to show all of what they did. Christodoulou (2010) proved that reflective practice as in e-portfolio raised job satisfaction and consequently helped teachers gain confidence to take part in critical decision-making about school policies and practices. For the second statement, Forawi, Almekhlafi \& Al-Mekhlafy (2012) and Alawdat (2013) found that using e-portfolios enhanced students' technical skills and increased their technological knowledge. Moreover, Mustafa (2011) verified that there is a major relationship between using e-portfolios and technical skills. For the last statement, Lorenzo and Ittleson (2005) demonstrated that e-portfolios facilitated the exchange of ideas and feedback. Feedback was vital to any improvement effort in teaching. On the other hand, "I was confused at the whole experience" and "I have found difficulties in selecting artifacts to document my work" received the least positive responses perhaps due to some assumptions. The confusion could be attributed to the other practical training demands the student teachers had to do in addition to developing their e-portfolios. These demands made them confused about finding enough time to arrange their work. Another possible reason behind the confusion was of the late introduction of e-portfolio since the student teachers were in the last year in college. This confusing experience aligned with the finding of a prior study of Roberts (2014), who found that the timing of the introduction of the e-portfolio was a main obstacle to the students' level of engagement with it. Many of his students mentioned that if they had started using e-portfolios from first year in college, they would have been more relaxed in using it and so quite engaged with it. For the difficulty in selecting artifacts, the researcher thought that most EFL student teachers were proud of all they did in the practical training, so they found it hard to choose the artifacts, which truly represent their best works and attributes.

Thirdly, the study proved that there were neither significant relations between EFL student teachers' e-portfolio scores and their attitudes towards the use of e-portfolio, nor between EFL student teachers' attitudes and their teaching performance. Though 30 participants were considered a reasonable number for this study, the sample size would be better if it was increased to measure the correlations accurately. The lack of relations could be attributed to the sample size, which may affect the results. Therefore, it seems crucial to continue to study such relations in order to prove their impact on teacher education and development and achieve more precise results.

However, there was a positive significant relation between EFL student teachers' e-portfolio scores and their teaching performance. Such a result pointed the positive role of e-portfolios on teaching performance. From the researcher's point of view, this relation was probably attributed to the following reasons:

- $\quad$ EFL student teachers' e-portfolios, which included records of their works and projects, were considered a rich environment for self-evaluation. This evaluation, which depended on continuous reflection of their teaching and objectives, probably contributed to their growth.

- Feedback, EFL student teachers received on their e-portfolios and reflections from their peers and supervisors, was vital to their teaching and fundamental to their progress.

- Internet probably contributed to improve EFL student teachers' knowledge, skills and abilities. Early eportfolios were often put onto CDs. The idea to use online platforms for making e-portfolios made EFL student teachers eager to create perfect digital representations of themselves. They searched the Internet and looked for new teaching ideas, activities and methods to show off their pedagogical potential.

This positive significant relation between EFL student teachers' e-portfolio scores and their teaching performance was supported with a group of previous studies. Pultorack (2010) highlighted the importance of developing e-portfolio programs to improve teachers' accountability and effectiveness. In addition, Winsor et al. (1999) and Kocoglu (2008) found evidences of a relation between the professional and personal development of teachers and their use of eportfolios. Furthermore, Sweigard (2007) proved that the continuous use of e-portfolios promoted teachers' written and oral proficiency. In a study conducted by Sanson (2013), teachers who had accomplished a portfolio had higher grades in their overall teaching ability. Besides, Christodoulou (2010) and Choy (2012) confirmed that reflective practices, such as e-portfolio usage, increased effectiveness among teachers, helping them to become more independent.

\subsection{Implications of the Study}

On the basis of data interpretation and conclusions of the study, the following recommendations were made:

1. Universities should give their students in advance enough lectures or workshops on how to employ eportfolio to the full potential of its use. There are many teacher e-portfolios available online that can be of a great value to the students.

2. Since it has already been proven that reflection is beneficial for shaping teacher's attitudes about change (Loughran, 1996), Critical thinking and reflection should be fostered in e-portfolios.

3. Most universities in Saudi Arabia have their own server where teachers can upload class materials and communicate with their students. It is recommended that such server provide appropriate space for students to develop their e-portfolios systematically. On the other hand, University instructors can regularly check and monitor student teachers' learning and performance through e-portfolios. 
5.3 Conclusions and Suggestions for Further Research

The present study proved that EFL student teachers were aware of the significance of e-portfolio integration in teacher education and its role to enhance teacher self-development. EFL student teachers showed a notable willingness and preference in using e-portfolios in language teaching, though they seemed to need more time and practice to build their e-portfolios. The study also demonstrated that there was a positive significant relation between the quality of EFL student teachers' e-portfolios and their teaching performance.

Furthermore, the results of this study were in alignment with the present research on the significance of technology integration in teacher education and development, however the following restrictions may have limited the scope of results:

1. The present study was conducted on only 30 EFL student teachers at Princess Noura University. The small number of participants limits the study results by preventing them from being generalizable to larger English teacher populations. Other studies can be conducted on a larger sample in different universities.

2. The current research was restricted to female participants, therefore, it is highly recommended to explore using e-portfolio on male student teachers at other Saudi universities as gender plays a paramount role in the study (Aslan, 2009).

3. The present study focused only on the relation of e-portfolio usage to the teaching performance. Other studies could investigate the effect of e-portfolio usage on particular aspects of teaching like lesson planning, teaching methods, assessment, etc. These studies might provide useful insights regarding eportfolio status as an effective educational tool.

4. As a new method in teacher education programs in Saudi Universities, students may encounter some constraints and problems in preparing their e-portfolios. Further studies could explore these constraints and problems for effective implementation of the e-portfolios.

5. Meyer, Abrami, Wade, Aslan, and Deault (2010) state that modern electronic tools have been adopted to meet the needs of the classroom, so further research can focus on investigating the positive consequences that teacher e-portfolio has on student progress in the classroom.

\section{Acknowledgments}

We would like to express our sincere appreciation to the participants for agreeing to participate in this study.

\section{References}

Abdal-Haqq, Ismat (1998). Constructivism in Teacher Education: Considerations for Those Who Would Link Practice to Theory. ERIC Clearinghouse on Teaching and Teacher Education, Washington DC. ED426986

Abu Mutlaq, H. (2012). The Effectiveness of Using E-Portfolio on Developing Some of Teaching Proficiencies for Teacher-Students at the Faculty of Education in Al-Aqsa University-Gaza. Al-Azhar University, Gaza.

Ahmad, I., Said, H.B., Zeb, A., Rehman, S., Ahmad, S., \& Khan, W. (2013). How reflective practice improves teachers' classroom teaching skill? A case of community based schools in district Chitral, Khyber Pakhtunkhwa. Social Sciences and Humanities, 4(1), 73-81.

Alawadat, M. (2013). Using E-portfolios and ESL Learners. US-China Education Review, 3(5), 339-351.

Alwraikat, Mansour (2012). Graduate Students' Attitudes towards the Use of Electronic-Portfolios in the College of Educational Sciences at the University of Jordan. International Journal of Humanities and Social Science, 2(12), 154163.

Andrade, Heidi (n.d). Understanding Rubrics by Heidi Goodrich Andrade. Retrieved from https://www.saddleback.edu/uploads/goe/understanding_rubrics_by_heidi_goodrich_andrade.pdf

Aslan, O. (2009). The role of gender and language learning strategies in learning English. Unpublished Master's thesis. Retrieved from http://etd.lib.metu.edu.tr/upload/12611098/index.pdf

Chen, D., Lumpe, A., \& Bishop, D. (2013). Assessment of Teacher Candidate Reflection in E-Portfolios. A paper presented at the annual EdMedia: World Conference on Educational Media and Technology, Victoria, Canada. Retrieved from https://www.learntechlib.org/p/112224.

Chien, C-W (2013). Pre-Service English Teachers' Perceptions and Practice of Electronic Portfolios. CALL-EJ, 14(1), 1-15. Retrieved from http://callej.org/journal/14-1/Chien_2013.pdf

Choy, C. (2012). Reflective Thinking and Teaching Practices: A Precursor for Incorporating Critical Thinking into the classroom? International Journal of Instruction, 5(1), 168-182.

Christodoulou, I. (2010). Teacher Self-Reflection. Brno, Czech: Masaryk University.

Cimermanova, I. (2015). Digital Portfolio in Building Teaching Efficacy of Pre-Service Teachers. Journal of Language and Cultural Education, 3(1), 57-66, ISSN (Online) 1339-4584, DOI: https://doi.org/10.1515/jolace-2015-0005 
Cohen-Sayag, E. (2012). Reflective Writing in Pre-Service Teachers' Teaching: What does it promote? Australian Journal of Teacher Education, 37(10), 20-35, DOI: http://dx.doi.org/10.14221/ajte.2012v37n10.1

Cronbach, L. J. (1951). Coefficient alpha and the internal structure of tests. Psychometrika, 16, 297-334.

De Grez, L., Valcke, M., \& Roozen, I. (2009). The impact of goal orientation, self-reflection, and personal characteristics on the acquisition of oral presentation skills. European Journal of Psychology of Education, 24(3), 293306.

Fareh, S. (2010). Challenges of teaching English in the Arab world: Why can't EFL programs deliver as expected? Procedia Social and Behavioral Sciences, 2(2), 3600-3604. DOI:10.1016/j.sbspro.2010.03.559

Forawi, S., Almekhlafi, A., \& Al-Mekhlafy, M. (2012). Development and Validation of E-Portfolios: The UAE Preservice Teachers' Experiences. US-China Education Review, 1(2), 99-105.

Granberg, C. (2010). E-portfolios in teacher education 2002-2009: The social construction of discourse, design and dissemination. European Journal of Teacher Education, 33(3), 309-322.

Herrington, J., Couros, A., \& Irvine, V. (2013). Assessment of Teacher Candidate Reflection in E-Portfolios. Retrieved from https://www.learntechlib.org/p/112224

Kemmis, S. (1994). Reflection: Turning experience into learning. London: Kogan Page Ltd.

Kocoglu, Z. (2008). Turkish EFL Student Teachers' Perceptions on the Role of E-Portfolios in their Professional Development. The Turkish Online Journal of Educational Technology, 7(3), 71-77.

Lorenzo, G., \& Ittelson, J. (2005).An overview of e-portfolios. Educause Learning Initiative, ELI Paper, 1-28. Retrieved from: https://net.educause.edu/ir/library/pdf/eli3001.pdf

Loughran, J. (1996). Developing Reflective Practice: Learning About Teaching and Learning through Modelling. London, UK: Taylor \& Francis.

Lumpe, A.T., Wicks, D., \& Williams, T. (2011). bPortfolios: Blog portfolios and self-tagging as reflective practice for teachers. A paper presented at the Sloan-C International Symposium on Emerging Technology Applications for Online Learning, San Jose, California.

Lyons, N. (1998). Reflection in teaching: Can it be developmental? A portfolio perspective. Teacher Education Quarterly, 25(1), 115-127.

Mair, C. (2012) Using technology for enhancing reflective writing, metacognition and learning, Journal of Further and Higher Education, 40(2), 147-167.

Meyer, E., Abrami, P., Wade, C., Aslan, O., \& Deault, L. (2010). Improving literacy and metacognition with electronic portfolios: Teaching and learning with ePEARL. Computers \& Education, 55(1), 84-91. DOI: http://dx.doi.org/10.1016/j.compedu.2009.12.005

Mustafa, A. A. M. (2011). The impact of electronic assessment-driven instruction on preservice EFL teachers' quality teaching. International Journal of Applied Educational Studies, 10(1), 18-35.

Noormohammadi, S. (2014). Teacher Reflection and its Relation to Teacher Efficacy and Autonomy. Journal of Social and Behavioral Sciences, 98(1), 1380 - 1389. doi:10.1016/j.sbspro.2014.03.556

Pultorak, E. (2010). The Purposes, Practices, and professionalism of Teacher Reflectivity (pp. 7-39). New York, NY: Rowman and Littlefield Education.

Rahman, M., \& Al Haisoni, E. (2013). Teaching English in Saudi Arabia: Prospects and Challenges. Academic Research International Journal, 4(1), 112-118.

Reflective Writing (n.d.). Retrieved from http://www.unbc.ca/sites/default/files/assets/academic_success_centre/writing_support/reflective_writing_151211_copy 1.pdf

Roberts, P. (2014). An ePortfolio environment to enhance reflection in pre-service teachers: What worked, what didn't and why? In A. Poot (Ed.), PebblePad: Personalising the curriculum (pp. 16-31). Telford: Pebble Learning Ltd.

Sanson, Jarrod Lance (2013) A Quantitative Study Focusing on the Effect of Electronic Portfolios in Teacher Education. Retrieved from http://etd.lsu.edu/docs/available/etd-06122013-083208/

Shulman, L.S. (1986). Those who understand: Knowledge growth in teaching. Educational Researcher, 15(2), 4-14.

Strudler, N., \& Wetzel, K. (2011). Electronic Portfolios in Teacher Education: Forging a Middle Ground. Journal of Research on Technology in Education, 44(2), 161-173.

Sweigard, T. (2007). Becoming a reflective practitioner as a preservice educator. E-Journal for Student Teachers and New Teachers, 1(2), 1-8.

Vandervelde,

https://www2.uwstout.edu/content/profdev/rubrics/eportfoliorubric.html

Rubric. $\quad$ Retrieved from 
Winsor, P., Burr, R., \& Reeves, H. (1999). Portraying Professional Development in Preservice Teacher Education: Can portfolios do the job? Journal of Teachers and Teaching: Theory and Practice, 5(1), 9-30. DOI: http://dx.doi.org/10.1080/1354060990050102

Yusuf \& Tuisawau (2011). Student Attitudes Towards the use of e-Portfolios: Experiences from The University of the South Pacific Malaysian. Journal of Educational Technology, 11(4), 31-41.

Appendix A. The Evaluation Rubric for E-portfolios

This rubric is designed to evaluate EFL Student Teachers' e-portfolios as a part of this research.

\begin{tabular}{|c|c|c|c|c|}
\hline Criteria & $\begin{array}{c}\text { Excellent } \\
100 \%\end{array}$ & $\begin{array}{c}\text { Proficient } \\
80 \%\end{array}$ & $\begin{array}{c}\text { Limited } \\
60 \%\end{array}$ & $\begin{array}{c}\text { Unsatisfactory } \\
40 \%\end{array}$ \\
\hline $\begin{array}{l}\text { Completeness of } \\
\text { Content } \\
30 \% \\
\text { Excellent } 30 \\
\text { Proficient } 24 \\
\text { Limited } 18 \\
\text { Unsatisfactory } 12\end{array}$ & 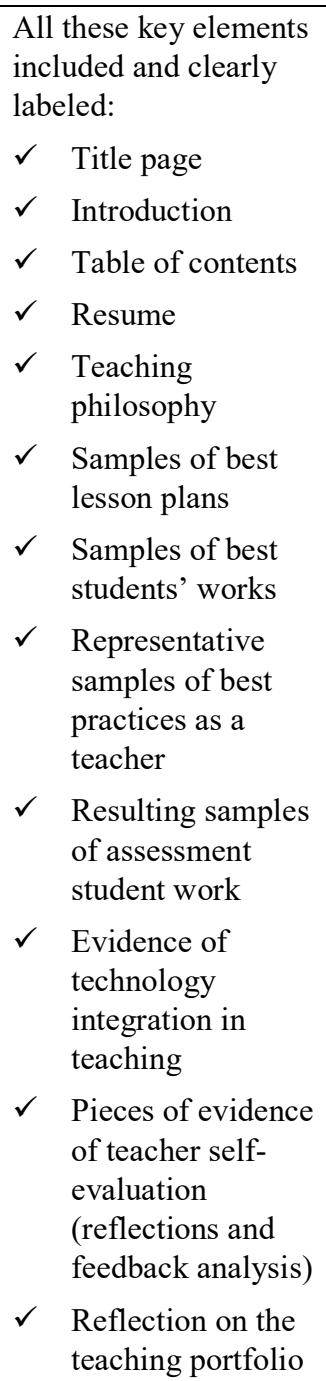 & $\begin{array}{l}\text { 1-2 elements are } \\
\text { missing or "thin" } \\
\text { Most or all elements } \\
\text { are clearly labeled }\end{array}$ & $\begin{array}{l}\text { 3-4 elements are } \\
\text { missing or "thin" } \\
\text { Elements are } \\
\text { labeled somewhat } \\
\text { clearly }\end{array}$ & $\begin{array}{l}5 \text { or more elements } \\
\text { missing or "thin" } \\
\text { Labels or sequence } \\
\text { are unclear }\end{array}$ \\
\hline $\begin{array}{l}\text { Reflection/Critique } \\
30 \% \\
\text { Excellent } 30 \\
\text { Proficient } 24\end{array}$ & $\begin{array}{l}\text { All reflections clearly } \\
\text { describe growth, } \\
\text { achievement, } \\
\text { accomplishments, and } \\
\text { include goals for } \\
\text { continued development } \\
\text { (long and short term). }\end{array}$ & $\begin{array}{l}\text { Most of the } \\
\text { reflections describe } \\
\text { growth and include } \\
\text { goals for continued } \\
\text { development. }\end{array}$ & $\begin{array}{l}\text { Few reflections } \\
\text { describe growth } \\
\text { and include goals } \\
\text { for continued } \\
\text { development. }\end{array}$ & $\begin{array}{l}\text { The reflections do } \\
\text { not describe } \\
\text { growth or include } \\
\text { goals for continued } \\
\text { development. }\end{array}$ \\
\hline $\begin{array}{l}\text { Limited } 18 \\
\text { Unsatisfactory } 12\end{array}$ & $\begin{array}{l}\text { All reflections illustrate } \\
\text { the ability to } \\
\text { effectively critique } \\
\text { work and provide } \\
\text { suggestions for }\end{array}$ & $\begin{array}{l}\text { Most of the } \\
\text { reflections illustrate } \\
\text { the ability to } \\
\text { effectively critique } \\
\text { work and provide }\end{array}$ & $\begin{array}{l}\text { Few reflections } \\
\text { illustrate the ability } \\
\text { to effectively } \\
\text { critique work and } \\
\text { provide }\end{array}$ & $\begin{array}{l}\text { The reflections do } \\
\text { not illustrate the } \\
\text { ability to } \\
\text { effectively critique } \\
\text { work or provide }\end{array}$ \\
\hline
\end{tabular}




\begin{tabular}{|c|c|c|c|c|}
\hline & $\begin{array}{l}\text { constructive practical } \\
\text { alternatives. }\end{array}$ & $\begin{array}{l}\text { suggestions for } \\
\text { constructive } \\
\text { practical } \\
\text { alternatives. }\end{array}$ & $\begin{array}{l}\text { suggestions for } \\
\text { constructive } \\
\text { practical } \\
\text { alternatives. }\end{array}$ & $\begin{array}{l}\text { suggestions for } \\
\text { constructive } \\
\text { practical } \\
\text { alternatives. }\end{array}$ \\
\hline $\begin{array}{l}\text { Use of Multimedia } \\
10 \% \\
\text { Excellent } 10 \\
\text { Proficient } 8 \\
\text { Limited } 6 \\
\text { Unsatisfactory } 4\end{array}$ & $\begin{array}{l}\text { All of the photographs, } \\
\text { concept maps, } \\
\text { worksheets, graphics, } \\
\text { audio and/or video files } \\
\text { effectively enhance } \\
\text { understanding of } \\
\text { concepts, ideas and } \\
\text { relationships, create } \\
\text { interest, and are } \\
\text { appropriate for the } \\
\text { chosen purpose. }\end{array}$ & $\begin{array}{l}\text { Most of the graphic } \\
\text { elements and } \\
\text { multimedia } \\
\text { contribute to } \\
\text { understanding } \\
\text { concepts, ideas and } \\
\text { relationships, } \\
\text { enhance the written } \\
\text { material and create } \\
\text { interest. }\end{array}$ & $\begin{array}{l}\text { Some of the } \\
\text { graphic elements } \\
\text { and multimedia do } \\
\text { not contribute to } \\
\text { understanding } \\
\text { concepts, ideas and } \\
\text { relationships. }\end{array}$ & $\begin{array}{l}\text { The graphic } \\
\text { elements or } \\
\text { multimedia do not } \\
\text { contribute to } \\
\text { understanding } \\
\text { concepts, ideas and } \\
\text { relationships. The } \\
\text { inappropriate use } \\
\text { of multimedia } \\
\text { detracts from the } \\
\text { content. }\end{array}$ \\
\hline $\begin{array}{l}\text { Navigation } \\
10 \% \\
\text { Excellent } 10 \\
\text { Proficient } 8 \\
\text { Limited } 6 \\
\text { Unsatisfactory } 4\end{array}$ & $\begin{array}{l}\text { The navigation links } \\
\text { are intuitive. The } \\
\text { various parts of the } \\
\text { portfolio are labeled, } \\
\text { clearly organized and } \\
\text { allow the reader to } \\
\text { easily locate an artifact } \\
\text { and move to related } \\
\text { pages or a different } \\
\text { section. All pages } \\
\text { connect to the Table of } \\
\text { Contents, and all } \\
\text { external links connect } \\
\text { to the appropriate } \\
\text { website or file. }\end{array}$ & $\begin{array}{l}\text { The navigation links } \\
\text { generally function } \\
\text { well, but it is not } \\
\text { always clear how to } \\
\text { locate an artifact or } \\
\text { move to related } \\
\text { pages or different } \\
\text { section. Most of the } \\
\text { pages connect to the } \\
\text { Table of Contents. } \\
\text { Most of the external } \\
\text { links connect to the } \\
\text { appropriate website } \\
\text { or file. }\end{array}$ & $\begin{array}{l}\text { The navigation } \\
\text { links are somewhat } \\
\text { confusing, and it is } \\
\text { often unclear how } \\
\text { to locate an artifact } \\
\text { or move to related } \\
\text { pages or a different } \\
\text { section. Some of } \\
\text { the pages connect } \\
\text { to the Table of } \\
\text { Contents, but in } \\
\text { other places the } \\
\text { links do not } \\
\text { connect to } \\
\text { preceding pages or } \\
\text { to the Table of } \\
\text { Contents. Some of } \\
\text { the external links } \\
\text { do not connect to } \\
\text { the appropriate } \\
\text { website or file. }\end{array}$ & $\begin{array}{l}\text { The navigation } \\
\text { links are confusing, } \\
\text { and it is difficult to } \\
\text { locate artifacts and } \\
\text { move to related } \\
\text { pages or a different } \\
\text { section. There are } \\
\text { significant } \\
\text { problems with } \\
\text { pages connecting } \\
\text { to preceding pages } \\
\text { or the Table of } \\
\text { Contents. Many of } \\
\text { the external links } \\
\text { do not connect to } \\
\text { the appropriate } \\
\text { website or file. }\end{array}$ \\
\hline $\begin{array}{l}\text { Layout } \\
10 \% \\
\text { Excellent } 10 \\
\text { Proficient } 8 \\
\text { Limited } 6 \\
\text { Unsatisfactory } 4\end{array}$ & $\begin{array}{l}\text { The e-portfolio is easy } \\
\text { to read. }\end{array}$ & $\begin{array}{l}\text { The e-portfolio is } \\
\text { generally easy to } \\
\text { read. }\end{array}$ & $\begin{array}{l}\text { The e-portfolio is } \\
\text { often difficult to } \\
\text { read due to } \\
\text { inappropriate use } \\
\text { of fonts and type } \\
\text { size for headings, } \\
\text { sub-headings and } \\
\text { text or inconsistent } \\
\text { use of font styles } \\
\text { (italic, bold, } \\
\text { underline). }\end{array}$ & $\begin{array}{l}\text { The e-portfolio is } \\
\text { difficult to read due } \\
\text { to inappropriate } \\
\text { use of fonts, type } \\
\text { size for headings, } \\
\text { sub-headings and } \\
\text { text and font styles } \\
\text { (italic, bold, } \\
\text { underline). }\end{array}$ \\
\hline $\begin{array}{l}\text { Quality of Writing } \\
10 \% \\
\text { Excellent } 10 \\
\text { Proficient } 8 \\
\text { Limited } 6 \\
\text { Unsatisfactory } 4\end{array}$ & $\begin{array}{l}\text { The writing is free of } \\
\text { grammatical, spelling } \\
\text { or punctuation errors. } \\
\text { The style of writing } \\
\text { facilitates } \\
\text { communication and no } \\
\text { editing is required. }\end{array}$ & $\begin{array}{l}\text { The writing is } \\
\text { largely free of } \\
\text { grammatical, } \\
\text { spelling or } \\
\text { punctuation errors. } \\
\text { The style of writing } \\
\text { generally facilitates } \\
\text { communication and } \\
\text { minor editing is } \\
\text { required. }\end{array}$ & $\begin{array}{l}\text { The writing } \\
\text { includes some } \\
\text { grammatical, } \\
\text { spelling or } \\
\text { punctuation errors } \\
\text { that distract the } \\
\text { reader and require } \\
\text { some editing and } \\
\text { revision. }\end{array}$ & $\begin{array}{l}\text { There are numerous } \\
\text { grammatical, } \\
\text { spelling or } \\
\text { punctuation errors. } \\
\text { The style of writing } \\
\text { does not facilitate } \\
\text { effective } \\
\text { communication and } \\
\text { requires major } \\
\text { editing and revision. }\end{array}$ \\
\hline
\end{tabular}




\section{Appendix B. The Questionnaire}

Dear student,

This questionnaire is part of my research to investigate EFL student teachers' attitudes towards the use of e-portfolio during their teaching practice. Your help is greatly needed and it will be highly appreciated. Your answers will remain confidential. Kindly, answer each one of the following questions by checking the blank that represents your opinion.

Name:

University ID:

\begin{tabular}{|c|c|c|c|c|c|c|}
\hline I. & Affective component & $\begin{array}{l}\text { Strongly } \\
\text { agree }\end{array}$ & Agree & Neutral & Disagree & $\begin{array}{l}\text { Strongly } \\
\text { disagree }\end{array}$ \\
\hline \multicolumn{7}{|c|}{ After the construction of my e-portfolio, } \\
\hline 1 & I have changed the way I look at myself. & & & & & \\
\hline 2 & I became more interested in my work. & & & & & \\
\hline 3 & I feel proud of my work. & & & & & \\
\hline 4 & My desire to teach effectively has been increased. & & & & & \\
\hline 5 & I was confused at the whole experience. & & & & & \\
\hline II. & Cognitive Component & & & & & \\
\hline \multicolumn{7}{|c|}{ After the construction of my e-portfolio, } \\
\hline 6 & I thought deeply about what I have learned. & & & & & \\
\hline 7 & $\begin{array}{l}\text { I thought about the connections of what I learned to what I } \\
\text { am going to teach. }\end{array}$ & & & & & \\
\hline 8 & $\begin{array}{l}\text { I discovered faults in what I had previously believed to be } \\
\text { right. }\end{array}$ & & & & & \\
\hline 9 & $\begin{array}{l}\text { I understood better my strengths and weaknesses in } \\
\text { teaching. }\end{array}$ & & & & & \\
\hline 10 & $\begin{array}{l}\text { I believed that e-portfolio fosters professional self- } \\
\text { analysis. }\end{array}$ & & & & & \\
\hline 11 & I think reflection is not of a great value to my growth. & & & & & \\
\hline 12 & $\begin{array}{l}\text { I learned a lot from communicating, interacting and } \\
\text { collaborating with peers. }\end{array}$ & & & & & \\
\hline 13 & I learned from reviewing my peers' e-portfolios online. & & & & & \\
\hline 14 & I improved my technology skills. & & & & & \\
\hline 15 & I increased my subject knowledge. & & & & & \\
\hline 16 & I am aware of my growth and development as a teacher. & & & & & \\
\hline III. & Behavioral Component & & & & & \\
\hline \multicolumn{7}{|c|}{ After the construction of my e-portfolio, } \\
\hline 17 & I became more organized in my work. & & & & & \\
\hline 18 & I have changed my normal way of doing things. & & & & & \\
\hline 19 & I could evaluate my lesson plans. & & & & & \\
\hline 20 & $\begin{array}{l}\text { I could modify my actions on my own to achieve my } \\
\text { goals. }\end{array}$ & & & & & \\
\hline 21 & $\begin{array}{l}\text { I could modify strategies that are not helping me achieve } \\
\text { my goals. }\end{array}$ & & & & & \\
\hline 22 & I used feedback from my supervisor to improve my work. & & & & & \\
\hline 23 & $\begin{array}{l}\text { I have found difficulties in selecting artifacts to document } \\
\text { my work. }\end{array}$ & & & & & \\
\hline 24 & $\begin{array}{l}\text { I plan to continue to update it when I am teaching full } \\
\text { time. }\end{array}$ & & & & & \\
\hline
\end{tabular}

